\title{
Chemo-adjuvant therapy in recurrent conjunctival intraepithelial neoplasia
}

She Poh Fong ${ }^{1,4}$, Khairidzan Mohd Kamal ${ }^{2}$, Akmal Haliza Zamli ${ }^{1}$, Norra Harun ${ }^{3}$, Safinaz Mohd Khialdin ${ }^{4}$

${ }^{1}$ Department of Ophthalmology, Hospital Tengku Ampuan Afzan, Kuantan, Pahang, Malaysia; ${ }^{2}$ Department of Ophthalmology, International Islamic University Malaysia, Kuantan, Pahang, Malaysia; ${ }^{3}$ Department of Pathology, Hospital Tengku Ampuan Afzan, Kuantan, Pahang, Malaysia; ${ }^{4}$ Department of Ophthalmology, Faculty of Medicine, Universiti Kebangsaan Malaysia, Cheras, Kuala Lumpur, Malaysia

\section{Abstract}

A 68-year-old Malay male with no known medical illness presented with progressive growth of right conjunctival mass over a few months. Anterior segment examination of the right eye showed an inferior perilimbal elevated gelatinous conjunctival mass measuring $6 \mathrm{~mm}$ vertically $\times 14 \mathrm{~mm}$ horizontally with $360^{\circ}$ corneal vascularisation. Excision biopsy and histopathological examination revealed areas of dysplastic cells involving the full epithelial thickness, suggestive of conjunctival intraepithelial neoplasia. The patient defaulted follow-up and presented later with recurrence involving the superior two-thirds of the cornea. Pulsed dosing of topical 5-fluorouracil $1 \%$ was initiated 4 times daily for a week with 21-day breaks for a total of 4 cycles. Regression of the lesion was noted after two cycles of 5-fluorouracil.

Keywords: chemo-adjuvant, conjunctival intraepithelial neoplasia, 5-fluorouracil

Correspondence: Khairidzan Mohd Kamal, MS Ophthal, Department of Ophthalmology, International Islamic University Malaysia, Jalan Sultan Ahmad Shah, Bandar Indera Mahkota, 25200 Kuantan, Pahang, Malaysia.

E-mail: khairidzan@gmail.com 


\section{Terapi kemo-adjuvan dalam neoplasia intraepitelial konjunktiva yang berulang}

\section{Abstrak}

Seorang lelaki Melayu berusia 68 tahun tanpa sebarang penyakit kronik menunjukkan pertumbuhan progresif jisim konjuntiva kanan selama beberapa bulan ini. Pemeriksaan klinikal segmen anterior mata kanan menunjukkan ketumbuhan bergelatin pada bahagian bawah perilimbal konjunktiva berukuran $6 \mathrm{~mm}$ (menegak) x $14 \mathrm{~mm}$ (mendatar) dengan pertumbuhan salurdarah yang memenuhi $360^{\circ}$ kornea. Pemeriksaan histopatologi pada biopsi secara eksisi menunjukkan kawasan sel displastik yang melibatkan semua lapisan ketebalan epitelia yang terarah kepada neoplasia intraepitelium konjunktiva. Pesakit gagal hadir rawatan susulan menyebabkan penyakit berulang dan merebak kepada dua pertiga kornea. Rawatan secara topikal 5-fluorouracil 1\% secara berkala diberi secara 4 kali sehari selama seminggu diikuti oleh rehat selama 21 hari diberikan sebanyak 4 kitaran. Regresi ketumbuhan diperhatikan selepas dua kitaran rawatan ini.

Kata kunci: kemo-adjuvan, neoplasia intraepithelial konjunktiva, 5-fluorouracil

\section{Introduction}

Conjunctival intraepithelial neoplasia (CIN) is a non-invasive lesion in which the conjunctival basement membrane remains intact and the underlying substantia propria spared. It commonly occurs over the bulbar conjunctiva in the interpalpebral zone with frequent involvement of the adjacent corneal epithelium. Clinically, it is difficult to distinguish between CIN and squamous cell carcinoma, which invades the epithelial basement membrane and substantia propria.

The treatment for CIN involves surgical excision with adjuvant alcohol and cryotherapy. Chemo-adjuvant and chemotherapeutic agents such as 5-fluorouracil (5-FU), mitomycin-C (MMC), and interferon alpha-2b (IFN) have shown promising results in the treatment of conjunctival premalignant lesions. ${ }^{1,2,3}$ Here, we report the role and effectiveness of delayed 5-FU treatment in a non-compliant CIN patient.

\section{Case report}

A 68-year-old Malay male with no known medical illness presented with progressive growth of conjunctival mass in the right eye over a few months. The best-corrected 
visual acuity was $3 / 60$ in the right eye and $6 / 9$ in the left eye. There was no relative afferent pupillary defect. Anterior segment examination of the right eye showed an inferior perilimbal elevated conjunctival mass measuring $6 \mathrm{~mm}$ vertically $\times 14 \mathrm{~mm}$ horizontally, with extensive corneal involvement of $360^{\circ}$ vascularisation (Fig. 1). Left eye examination was unremarkable. There was no palpable preauricular, submandibular, or cervical lymphadenopathy. The patient underwent excision biopsy with non-touch technique and histological examination revealed areas with dysplastic cells involving the full epithelial thickness, suggestive of CIN (Figs. 2 and 3). He was planned for chemo-adjuvant therapy of topical 5-FU. However, the patient defaulted treatment and presented later with a recurrent lesion involving the superior two-thirds of the cornea with extensive corneal vascularisation (Fig. 4). The patient was then recommenced on 5-FU $1 \% 4$ times daily for a week for 4 cycles with a resting time of 21 days between the cycles. The conjunctival growth responded to treatment, shrinking by 2 clock hours and became less vascular (Fig. 5). His vision improved to $6 / 9$.

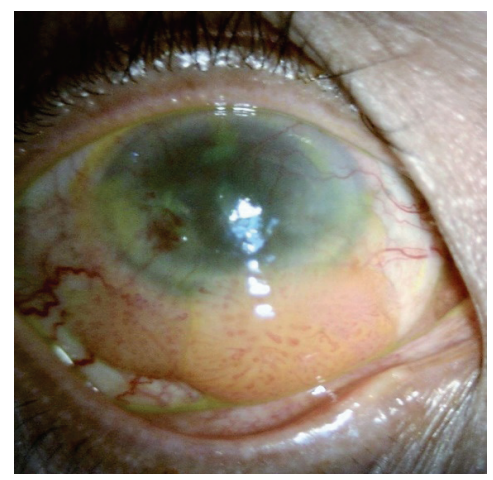

Fig. 1. Anterior segment examination of the right eye showed an inferior perilimbal elevated conjunctival mass measuring $6 \mathrm{~mm}$ vertically $\times 14 \mathrm{~mm}$ horizontally, with a gelatinous surface.

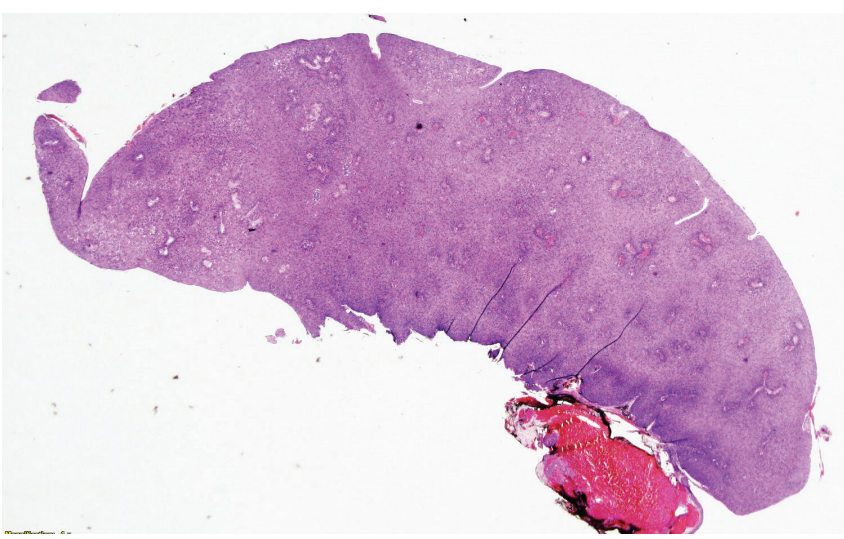

Fig. 2. The slide showing full thickness of dysplastic cells (carcinoma in situ).

H\&E: $\times 20$ magnification 


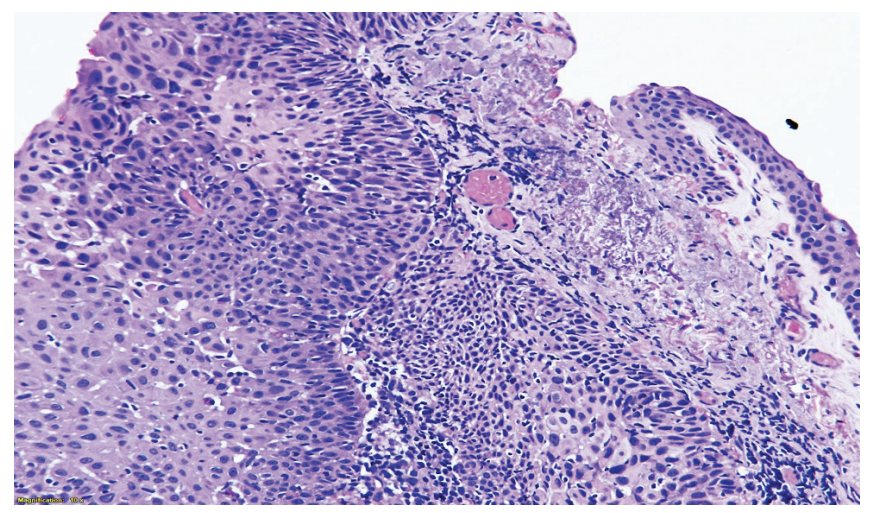

Fig. 3. The dysplastic epithelium on the left (asterisk) showed increased cellularity and loss of normal maturation sequence. The slides showed intact basement membrane with an area of normal conjunctival epithelium (arrow). H\&E: x100 magnification

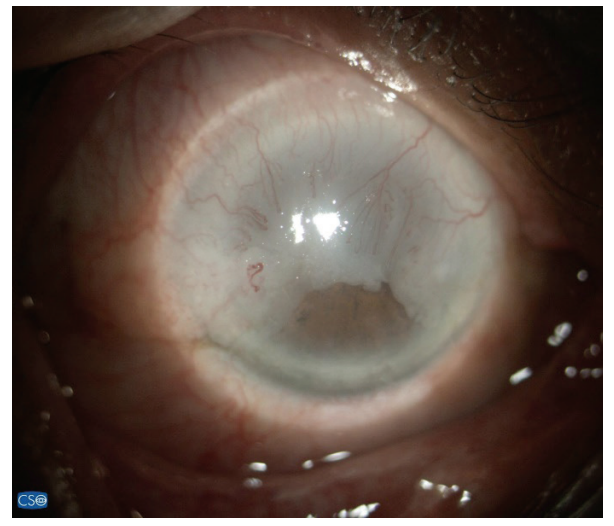

Fig. 4. The recurrence of the conjunctival lesion involving the superior two-thirds of cornea, covering the visual axis with extensive corneal vascularisation.

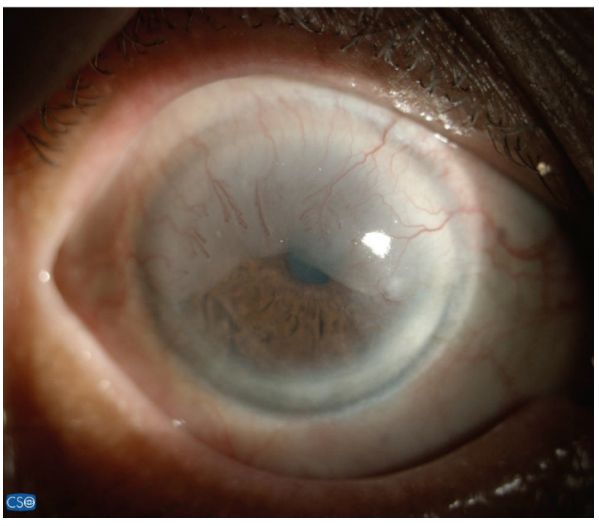

Fig. 5. After two cycles of 5-FU therapy. The conjunctival lesion was reduced in size by two clock hours with less vascularity.

\section{Discussion}

$\mathrm{CIN}$, including carcinoma in situ, are uncommon clinical entities. The exact aetiology of CIN is unknown with multifactorial possible contributing factors. The known risk factors include older age, fair pigmentation, ultraviolet light exposure, exposure to petroleum products, human papillomavirus, and human immunodeficiency virus (HIV). ${ }^{4}$ It is difficult to cure, as it exhibits conjunctivalization, which is prone to multiple recurrences, ${ }^{2}$ as shown in this case. 
Surgical excision can be used for therapeutic and diagnostic purposes. Before the introduction of chemotherapeutic modalities, traditional therapy involved surgical excision with adjunctive cryotherapy or radiation. However, recurrence rates of up to $33 \%$ have been reported, even with clear margins evidenced by pathologic results. ${ }^{1}$

As a sole therapy, topical 5-FU is a long-term, safe, and effective treatment modality for preinvasive ocular surface squamous neoplasia and for almost half of invasive ocular surface squamous neoplasia. ${ }^{3}$ Thus, it is an option to start 5-FU first in cases of CIN which can only be diagnosed clinically without histopathology confirmation. Topical chemotherapy has proven benefits when compared to traditional surgical excision and cryotherapy. The advantages include reducing the tumour size and eradicating the histological, non-visible nests of tumour cells. Furthermore, it does not cause limbal stem cell deficiency, which is associated with more destructive therapies involving the limbus. ${ }^{2}$ Common side effects include conjunctival and corneal inflammation, corneal epithelial defects, and eye irritation.

The standard dosage of topical 5 -FU reported is $1 \%$ in aqueous solution, 4 times a day over 4 weeks. A few authors used pulsed dosing with topical 1\% 5-FU 4 times daily but limiting the dose to $2-4$ days in 4-6 cycles, with an interval of 30-45 days without treatment. ${ }^{2,5}$ Pulsed dosing regimens have been found to be as effective as continuous dosing regimens, with a reduced side effect profile., ${ }^{3,5,6}$

This case illustrates the reality of delivering medical care in our daily practice, as non-compliance occurs due to various reasons. The decision to restart the chemo-adjuvant was made in light of the histological findings and to prevent further loss of opportunity in treating the lesion.

\section{Conclusion}

In view of the high recurrence rate and surgical difficulties in cases with corneal extension, topical 5-FU is advocated as a chemo-adjuvant in the treatment of CIN to prevent local recurrence after excision biopsy with promising results. It should be instituted at the earliest opportunity available and can even be started in default cases.

\section{References}

1. Tabin G, Levin S, Snibson G, Loughnan M, Taylor H. Late recurrences and the necessity for long-term follow-up in corneal and conjunctival intraepithelial neoplasia. Ophthalmology. 1997;104(3):485492. 
2. Al-Barrag A, Al-Shaer M, Al-Matary N, Al-Hamdani M. 5-Fluorouracil for the treatment of intraepithelial neoplasia and squamous cell carcinoma of the conjunctiva, and cornea. Clin Ophthalmol. 2010;4:801-808.

3. Parrozzani R, Frizziero L, Trainiti S, et al. Topical 1\% 5-fluoruracil as a sole treatment of corneoconjunctival ocular surface squamous neoplasia: long-term study. Br J Ophthalmol. 2017;101(8):10941099.

4. Giaconi JA, Karp CL. Current treatment options for conjunctival and corneal intraepithelial neoplasia. Ocul Surf. 2003;1(2):66-73.

5. Midena E, Lazzarini D, Catania AG, Moretto E, Fregona I, Parrozzani R. Cytostatic and cytotoxic effects of 5-fluorouracil on human corneal epithelial cells and keratocytes. Cornea. 2013;32(3):338-344.

6. Yeatts RP, Engelbrecht NE, Curry CD, Ford JG, Walter KA. 5-Fluorouracil for the treatment of intraepithelial neoplasia of the conjunctiva and cornea. Ophthalmology. 2000;107(12):2190-2195. 